\title{
Dohánytermő területek talajtani-agrokémiai felmérése 1990. és 1991. években
}

\author{
KÁDÁR IMRE és GONDOLA ISTVÁN \\ MTA Talajtani és Agrokémiai Kutatóintézet, Budapest \\ Debreceni Egyetem, Agrárcentrum Kutató Központ, Nyíregyháza
}

\section{Bevezetés és irodalmi áttekintés}

Mióta Kolumbusz 1492-ben megtalálta a dohányt Közép-Amerikában, az egész világon elterjedt. Értékes, belterjes, munkaigényes kultúrává vált, melyet ma mintegy 5 millió ha-on termelnek. Ez a szántó $0,06 \%$-át jelenti. Jelentősége azonban szinte nagyságrenddel nagyobb területi részarányánál termelési értéke miatt. Hazánkban az 1980-as években a szántó 0,2\%-át foglalta el, évi 10 ezer ha körüli területtel. Jelentősége azóta némileg visszaszorult.

A Nicotiana nemzetségnek két faja jelentős gazdaságilag. A kizárólag ipari célokra termelt Kapadohány ( $N$. rustica L.) és az élvezeti célra termelt dohány ( $N$. tabacum L.). A továbbiakban a $N$. tabacum fajjal foglalkozunk, melyet szintén sokféleség jellemez. A következőképpen osztályozzák a felhasználás és a szárítás módja szerint (CHOUTEAU \& FAUCONNIER, 1988): hány;

- Virginia típusú mesterséges szárítású (flue-cured) cigarettadohány és pipado-

- Kentucky típusú füstöléssel száradó cigarettadohány, pipadohány és rágódohány;

- Keleti típusú napon száradó cigarettadohány és pipadohány.

A Virginia fajtákat Magyarországon az 1930-as évek óta termesztik. A száraz levéltermés 1-2 t/ha, ami elmarad a kedvezőbb ökológiai adottsággal rendelkező országoktól. A palántázás májusban történik, a virágzás 60-70 nap múlva augusztus elejéig kiteljesedik és ezzel az aljlevelek technikai érése is bekövetkezik. A virágzat eltávolítása (tetejezés vagy bugázás) idején kerülhet sor az aljlevelek törésére, majd 7-10 naponként, 4-5 menetben a további levélszintek eltávolítására. A betakarítás így szeptember végéig elhúzódik, mert mindig csak az érett leveleket törik le, válogatottan. Az egyéves dohány 6-8 hetet palántaágyban tölt, így a teljes tenyészidő hossza hazánkban a 6-7 hónapot is elérheti, melyböl 4-5 hónap a szabadföldi idöszak (GONDOLA, 1988).

BORSOS (1976) szerint a Virginia fajták a 20-30\% leiszapolható részt meg nem haladó, 28-37 kötöttségủ $\left(\mathrm{K}_{\mathrm{A}}\right), 5-7 \mathrm{pH}(\mathrm{KCl})$-értékkel jellemzett talajokon díszle-

Postai cím: KÁDÁR IMRE, MTA Talajtani és Agrokémiai Kutatóintézet, 1022 Budapest, Herman Ottó út 15. E-mail: kadar@rissac.hu 
nek megfelelően. A kifejezetten lúgos, vagy erősen savas talaj nem alkalmas dohánytermesztésre. Hasonlóképpen a sós, szikes-szódás talajok sem. Meszezést ott javasolnak, ahol a hidrolitos aciditás 4 fölé emelkedik. A fent említett homokos és homokos-vályog talajokon vékony levelü finom cigarettadohány terem.

A dohány igazi hazája a Nyírség, mely az ottani homoki területek legértékesebb szántóföldi növénye. Kézimunka szükséglete nagy, ezért döntően kisüzemi jelleggel termesztik. Szinte az egész évben elfoglaltságot ad. Kora tavasszal kezdődik a palántanevelés, majd ezt követi a kiültetés, a többszöri kapálás, nyáron a tetejezés/kacsozás, az őszre áthúzódó többszöri törés, a levelek szárítása, télen a válogatás, csomózás. Mủvelése speciális ismereteket igényel, termesztésével nagyüzemekben állandó csoportok foglalkoztak. Hazánkban a dohánytermő terület 2/3-a a Nyírségben található és itt terem a Virginia dohányok zöme. A levél általában 2-3\% nitrogént tartalmaz, füstjének kémhatása savas. A nikotintartalom 1-2\% körüli a kívánalmaknak megfelelően, a redukáló cukoré pedig kedvezően nagy, $12 \%$ feletti értékkel.

A dohány művelése nemcsak megélhetést biztosított a lakosság egy részének az ország egyik legszegényebb vidékén, de kultúrát is teremtett. Történetileg szemlélve hatással volt az egész mezőgazdaság belterjessé tételében. Elővetemény értéke kiváló, hiszen gondos ápolást és trágyázást igényel a talaj kultúrállapotát és termékenységét növelve. A dohány ilyetén sokoldalú pozitív hatását a gazdálkodásra már a klasszikus irodalom is kiemeli (DITZ, 1867; CSERHÁTI, 1900).

A minőség viszonylagos fogalom amennyiben a felhasználás céljától függ. A termék tulajdonságainak olyan együttesét jelenti, mely kielégítheti a felhasználók igényeit. A minőség megítélése térben és időben változhat, ahogy az igények módosulnak. Természetszerüen mást jelent a minőség a fogyasztónak és a feldolgozóiparnak. A fogyasztó a megfelelö íz, illat, éghetöség és a minimális egészségkárosító hatásban érdekelt. Az ipar ugyan alárendeli érdekeit a piacnak, de számára a feldolgozás hatékonysága is alapvető szempont. A szabványokban megadott minöségi osztályok a hozzárendelt átvételi árakkal közvetítik az ipar és a piac kívánalmait a termelő felé. A Virginia száraz dohány minőségi osztályai között 500\%-os árkülönbség volt pl. 1989-ben (GONDOLA, 1989).

Az ény-európai szakirodalom a kálium meghatározó szerepét hangsúlyozza mind a termés, mind a minőség tekintetében (BECKER-DILLINGEN, 1934; USHERWOOD, 1985; GETHING, 1990). A tengeri vagy jégkori üledéken képződött durvaszövetü homokos talajok ugyanis káliumban szegények. Mint PRJANISNYIKOV (1965) megjegyzi, Oroszország és K-Európa talajain a kálium ritkán minimum tényező, Ny-Európa tapasztalataival ellentétben. Gyakori viszont a P-hiány és a Ntúlsúly a dohánytermesztésben. A nitrogén a levélben tág határok (tenyészedényben 0,5-3,9\%) között ingadozik. A 2\% alatti N-tartalom hiányt jelez. Ilyenkor gátolt a növekedés, a klorofill-, fehérje- és a nikotin szintézise, a dohányfüst ízetlenné válik, az alsó levelek sárgulnak és leszáradnak. A fajtától függően 3-4\% N-tartalom felett viszont luxuskínálat áll elö.

A P-tartalom a levélben általában szükebb tartományban $(0,2-0,4$ P\%) ingadozik. A 0,2 alatti P\% a levélben hiányt jelez, mely a foszforral gyengén ellátott talajon föként hideg tavaszon lép fel, amikor a P-felvétel a talajból korlátozott. A P- 
hiány lassú növekedést és érést eredményez, valamint gátolja az egyéb elemek (mint a N és K) beépülését. A levélben felhalmozódnak a félkész termékek: aminosavak és ásványi-N a fehérje-N helyett, részben cukrok a keményítő, ill. zsírsavak az olajok helyett.

A kálium extrém módon 1-8\% között ingadozhat a levélben luxusfelvétele miatt. Kifejezett hiányról 2\% alatti K-tartalom esetén beszélünk, a kielégítő ellátottságot 2-4 K\% jelentheti. A levél K-tartalma a minőséget is jelzi, így fontos értékmérő tulajdonság. A luxusfelvétel kívánatos, mert a K-túlsúly javítja a szárazságtürést, betegség-ellenállóságot, a cigaretta minőségét (mint a cukortartalom, éghetőség, élvezhetőség), valamint mérsékli a káros $\mathrm{N}$-vegyületek, alkaloidák és nikotin menynyiségét. Kedvező az 1-3\% közötti Ca-tartalom (öregedö levelekben nagyobb felhalmozódás), valamint a $0,3-0,8 \% \mathrm{Mg}$ jelenléte. Mivel a $\mathrm{K}, \mathrm{Ca}$ és $\mathrm{Mg}$ kationok antagonizmusa kifejezett, fontos a $\mathrm{K} / \mathrm{Ca}, \mathrm{K} / \mathrm{Mg}, \mathrm{Ca} / \mathrm{Mg}$ arányok figyelemmel kísérése. GONDOLA (1990) szerint a makroelemek optimális arányai az alábbiak lehetnek: K/P 10-15, K/Mg 8-12, N/P 7-12, Ca/Mg 3-6, K/Ca 1,5-2,5, ill. az N/K 0,61,2 .

A fontosabb esszenciális mikroelemek minőségre gyakorolt hatásáról kevés tudósítás látott napvilágot. A dohánylevél optimális elemtartalmát az $50-150 \mathrm{mg}$ Mn-, 20-80 mg B- és Zn-, 10-20 mg Cu- és $0,2-0,6 \mathrm{mg} / \mathrm{kg}$ Mo-tartalmak tükrözhetik. Az utóbbi időben több figyelmet fordítanak a dohány fémszennyeződésére. CogBILl és HobBS (1957) a cigarettákban 2,48\% K-, 2,61\% Ca-, 0,48\% Mg-, 805 mg Na-, 630 mg Al-, 515 mg Fe-, 180 mg Mn-, 37 mg Cu-, 30 mg Zn-, 19 mg Pb-, $13 \mathrm{mg}$ As-, $2 \mathrm{mg}$ Ni- és $1 \mathrm{mg}$ Cr-mennyiséget talált $1 \mathrm{~kg}$ száraz levélben. Szerzők szerint az emelkedett $\mathrm{Pb}$ - és As-tartalom a növényvédő szerekből származhat. A fémek oxidok és karbonátok formájában a cigarettahamuban maradnak. A füstbe a fémek alig 1\%-a kerülhet, ebböl $90 \% \mathrm{~K}$, és $5 \% \mathrm{Na}$ a fóáramban az említett szerzők szerint.

A dohányzás kimutathatóan járul hozzá a humán Cd-terheléshez. A dohányosok veséjében általában kétszeres Cd-mennyiség fordul elö. A kadmium gyorsan elillan a levél égésekor és 5-20\%-a a föáramba kerülhet és belélegezzük. A $40-80 \%$ az oldaláramot gazdagítja és passzívan a nemdohányzó lélegezheti be. A belélegzett Cd 40-50\%-át a tüdő megkötheti és a továbbiakban egy része a vesében felhalmozódhat BELL és munkatársai (1988) szerint, ezért szennyezett talajon dohány nem termeszthető. A szerzök szabadföldi kísérletükben 0, 56, 112, 224 t/ha érlelt szennyvíziszapot adtak, mely $1300 \mathrm{mg} \mathrm{Zn,} 570 \mathrm{mg} \mathrm{Cu}, 280 \mathrm{mg} \mathrm{Pb}, 45 \mathrm{mg}$ Ni és 13 mg Cd elemet tartalmazott kg szárazanyagban. A 10 . év után termesztett dohány levelében a Ni 1-ről 8, a Cd 5-ről 20, a Cu 10-röl 40, Zn 50-ről 800, Mn 100-ról 800 $\mathrm{mg} / \mathrm{kg}$ értékre ugrott a maximális terhelés nyomán a kontrollhoz viszonyítva. Az $\mathrm{Pb}$-tartalom a levélben nem változott.

A továbbiakban megkíséreljük bemutatni az 1990. és 1991. évi országos dohánytermő területek felmérési eredményeit, a termőhelyek és termőtájak talajvizsgálati, termés- és levélvizsgálati adatait. Összefüggéseket keresünk a talajtulajdonságok és a levél minőségi jellemzői között. A sokezres adattömeg részletes elemzése áttekintést nyújthat egyben a hazai dohánytermő talajok, táblák állapotáról, a termett dohánylevél elemösszetételéről, káros nehézfémtartalmáról is a vizsgált 
években. Hasonlóan nagyszabású és interdiszciplináris megközelítést igénylő felmérésre korábban nem került sor, így jelen közlemény hiányt pótolhat a hazai szakirodalomban. A hazai és nemzetközi szakirodalom alapján a dohány ásványi táplálásáról ezt megelőzően már áttekintést adtunk (KÁDÁR, 2006).

\section{Anyag és módszer}

A vizsgálatokba összesen 192 dohánytermő üzemet/táblát vontunk be, melyeken Virginia típusú dohányt termesztettek kereskedelmi céllal. A gazdaságokat véletlenszerủen választottuk ki (1990-ben 112, 1991-ben 80), eloszlásuk arányos volt a Virginia termőterületével régióként és országosan is. A talajmintákat részben a dohánytermeltető vállalat körzeti szaktanácsadója, részben a gazdálkodó vette az elöírt MÉM NAK (1978) útmutatás szerint a szántott rétegböl a kiültetés, ill. a mütrágyázás elött. A táblánként begyüjtött 2-2 átlagminta minimum 10-10 fúrás öszszekeveréséből készült. A levélmintákat a dohány beváltásakor, tehát az értékesítéskor a beváltó-üzemi termeltető szakember vette. Az átlagminta $0,5 \mathrm{~kg}$-ot tett ki több helyről véve a „B” válogatási osztályból. Ekkor állapították meg a légszáraz termés tömegét is.

A dohányökológiai felmérésbe bevontuk a nyírlugosi dohány tartamkísérlet meszezési és mütrágyázási kezeléseit is: $\mathrm{N}, \mathrm{NK}, \mathrm{NPK}, \mathrm{NPK}+\mathrm{Ca}, \mathrm{NPK}+\mathrm{Mg}$, $\mathrm{NPK}+\mathrm{Ca}+\mathrm{Mg}$. A kezelésenkénti 2-2 ismétlés 14 adattal bővítette adatbázisunkat. A kísérlet módszerét és körülményeit korábban már részletesen ismertettük (KÁDÁR \& SZEMES, 1994).

A talajmintákat a Debreceni Növény- és Talajvédelmi Állomás (NTÁ) fogadta és elemezte a szabványok elöírásai szerint (BARANYAI et al., 1987) az alábbi jellemzökre: $\mathrm{pH}, \mathrm{K}_{\mathrm{A}}$, összes só, $\mathrm{CaCO}_{3}$, humusz, $\mathrm{NO}_{3}+\mathrm{NO}_{2}-\mathrm{N}$, AL-oldható P-, $\mathrm{K}$ - és Na-, KCl-oldható Mg-, $\mathrm{KCl}+\mathrm{EDTA}$ oldható Mn-, Zn- és Cu-tartalom. Ezt követően az MTA Talajtani és Agrokémiai Kutatóintézetben (MTA TAKI) meghatároztuk a cc. $\mathrm{HNO}_{3}+$ cc. $\mathrm{H}_{2} \mathrm{O}_{2}$ feltárásból az ún. „összes”, ill. a LAKENEN és ERVIÖ (1971) által ajánlott módon az $\mathrm{NH}_{4}$-acetát+EDTA-oldható 22 elemet, ICP technikát alkalmazva.

A Debreceni Dohánykutató és Fejlesztő Intézet laboratóriuma állapította meg a levélminták N, összes alkaloida és redukáló cukor \%-át az Intézetben elfogadott rutin eljárásokkal (Módszerkönyv, 1968). A Debreceni NTÁ a növényminták összetételét cc. $\mathrm{H}_{2} \mathrm{SO}_{4}+\mathrm{cc} . \mathrm{H}_{2} \mathrm{O}_{2}$ roncsolás után $\mathrm{N}, \mathrm{P}, \mathrm{K}, \mathrm{Ca}, \mathrm{Mg}, \mathrm{Na}, \mathrm{Fe}, \mathrm{Mn}, \mathrm{Zn}$ és $\mathrm{Cu}$ elemekre határozta meg. Ezt követően az MTA TAKI-ban cc. $\mathrm{HNO}_{3}+$ cc. $\mathrm{H}_{2} \mathrm{O}_{2}$ feltárásból 22 elemet vizsgáltunk ICP technikát alkalmazva. A termés, beváltási ár, bevétel és a Világos Válogatási Osztály adatait a Dohánykutató Intézet rögzítette.

A sokezres adatállományt többféleképpen csoportosítottuk: $\mathrm{pH}(\mathrm{KCl})$, beváltókörzetek, nagytájak és évek szerint, valamint bemutattuk az adatok és mért jellemzők szórását., minimum-maximum értékeit, átlagait és korrelációkat számítottunk a talaj- és növényelemzési adatok, ill. a növényi összetétel és néhány környezeti tényező között. A felmérés körülményeiről, néhány részeredményről korábban már beszámoltunk (GONDOLA \& KÁDÁR, 1994-1995). 
Ami a dohánytermés minőségét és mennyiségét meghatározó kritikus júniusi és júliusi hónapok csapadékösszegét érinti megállapítható volt, hogy 1990. év aszályosnak minősült a 99 mm kéthavi csapadékkal, míg az 1991. évben ugyanezen idő alatt lehullott $166 \mathrm{~mm}$ kedvezőbb feltételeket teremtett a növény fejlődéséhez és a jobb levélminőség létrejöttéhez.

\section{Eredmények}

Amint az 1. táblázat adatai mutatják, a dohánytermő talajok tulajdonságai rendkívüli mértékben és széles sávban szórtak. Egyaránt magukban foglalják az erősen meszes savanyú; a humuszban igen szegény és szerves anyagban gazdag; a laza homok és kötött vályog; oldható makro- és mikroelemekben extrém módon szegény és túlsúlyos vagy szennyezett talajokat. Ami az „oldható” elemkészleteket illeti, pl. az AL-PK tartalomban 20-szoros; a KCl-oldható $\mathrm{NO}_{3}$-N-ben 41 -szeres, ill. a $\mathrm{Mg}$ készletben 57-szeres; az EDTA-Cu tartalomban 280-szoros, ill. az EDTA-Zn készletben 830-szoros eltérést találtunk a minimum és maximum értékek között.

A 2. táblázatban a dohánytermö területek talajvizsgálati eredményeit talajcsoportokba rendeztük. Az összes termőhely $63 \%$-át savanyú homok, $28 \%$-át a meszes homoktalajok képezik. A homok termőhelyek aránya tehát 91\%-ot tett ki. A kötött talajok kereken 8 , míg a kotus talajok 1\%-os arányt képviseltek. A talajcsoportok szerint változnak az alaptulajdonságok alapértékei, mint a $\mathrm{pH}(\mathrm{KCl}), \mathrm{CaCO}_{3}, \mathrm{~K}_{\mathrm{A}}$. Látható, hogy a kotus talajok szerves anyagban gazdagok, de a $\mathrm{NO}_{3}$-N-készletük csekély. Az oldható Na-, Mg- és Mn-készletet tekintve a kötött talajú termőhelyek, az AL-PK-készlet alapján a kotus és kötött talajú termőhelyek gazdagok leginkább. A Zn-szennyezés meszes homoktalajokon lehet jelentős.

\section{1. táblázat}

Az 1990. és 1991. évi vizsgálatokba vont dohánytermő területek szántott rétegének talajvizsgálati jellemzői (Debreceni NTÁ, $n=206$ )

\begin{tabular}{|lc|c|c|c|c|}
\hline \multicolumn{2}{|c|}{$\begin{array}{c}\text { Mért talajjellemzö és } \\
\text { mértékegysége }\end{array}$} & $\begin{array}{c}(2) \\
\text { Minimum } \\
\text { érték }\end{array}$ & $\begin{array}{c}\text { Maximum } \\
\text { érték }\end{array}$ & $\mathrm{CV} \%$ & Átlag \\
\hline $\mathrm{CaCO}_{3}$ & $\%$ & 0,0 & 11,5 & 182 & 1,6 \\
a) $\mathrm{Humusz}_{\mathrm{pH}(\mathrm{KCl})}$ & $\%$ & 0,3 & 6,1 & 63 & 1,2 \\
$\mathrm{KCl}-\mathrm{NO}_{3}$-N & $\mathrm{mg} / \mathrm{kg}$ & 1,7 & 6,1 & 26 & 5,6 \\
$\mathrm{~b}) \mathrm{Kötöttség}\left(\mathrm{K}_{\mathrm{A}}\right)$ & & 25,0 & 53,4 & 69 & 16 \\
$\mathrm{AL}-\mathrm{Na}$ & $\mathrm{mg} / \mathrm{kg}$ & 1 & 104 & 17 & 27 \\
$\mathrm{KCl}-\mathrm{Mg}$ & $\mathrm{mg} / \mathrm{kg}$ & 13 & 744 & 120 & 25 \\
$\mathrm{AL}-\mathrm{P}_{2} \mathrm{O}_{5}$ & $\mathrm{mg} / \mathrm{kg}$ & 47 & 920 & 66 & 274 \\
$\mathrm{AL}-\mathrm{K}_{2} \mathrm{O}$ & $\mathrm{mg} / \mathrm{kg}$ & 43 & 868 & 60 & 282 \\
EDTA-Cu & $\mathrm{mg} / \mathrm{kg}$ & 0,2 & 56 & 188 & 5 \\
EDTA-Zn & $\mathrm{mg} / \mathrm{kg}$ & 0,4 & 332 & 538 & 7 \\
EDTA-Mn & $\mathrm{mg} / \mathrm{kg}$ & 10,1 & 337 & 73 & 119 \\
\hline
\end{tabular}




\section{2. táblázat}

Az 1990. és 1991. évi vizsgálatba vont dohánytermő területek szántott rétegének talajvizsgálati jellemzői talajcsoportok szerint (Debreceni NTÁ vizsgálatai)

\begin{tabular}{|c|c|c|c|c|c|c|}
\hline \multirow{3}{*}{$\begin{array}{c}\text { Vizsgált jellemző } \\
\text { és } \\
\text { mértékegysége }\end{array}$} & $\begin{array}{c}\text { (2) } \\
\text { Savanyú }\end{array}$ & $\begin{array}{c}(3) \\
\text { Meszes } \\
\end{array}$ & $\begin{array}{c}\text { (4) } \\
\text { Összes } \\
\end{array}$ & \multirow{3}{*}{$\begin{array}{c}(6) \\
\text { Kötött } \\
\text { talaj } \\
(\mathrm{n}=16) \\
\end{array}$} & \multirow{3}{*}{$\begin{array}{c}(7) \\
\text { Kotus } \\
\text { talaj } \\
(\mathrm{n}=2) \\
\end{array}$} & \multirow{3}{*}{$\begin{array}{c}\text { (8) } \\
\text { Összes } \\
\text { termőhely } \\
(\mathrm{n}=206)\end{array}$} \\
\hline & \multicolumn{3}{|c|}{ (5) homoktalaj } & & & \\
\hline & $(n=130)$ & $(\mathrm{n}=58)$ & $(n=188)$ & & & \\
\hline $\mathrm{CaCO}_{3}, \%$ & 0,0 & 5,3 & 1,6 & 0,8 & 0,0 & 1,6 \\
\hline a) Humusz, \% & 1,0 & 1,2 & 1,1 & 2,4 & 6,1 & 1,2 \\
\hline $\mathrm{pH}(\mathrm{KCl})$ & 4,7 & 7,6 & 5,6 & 6,2 & 4,9 & 5,6 \\
\hline $\mathrm{KCl}-\mathrm{NO}_{3}-\mathrm{N}, \mathrm{mg} / \mathrm{kg}$ & 16 & 14 & 16 & 22 & 9 & 16 \\
\hline b) Kötöttség $\left(\mathrm{K}_{\mathrm{A}}\right)$ & 26 & 27 & 26 & 42 & 28 & 27 \\
\hline AL-Na, mg/kg & 18 & 34 & 23 & 48 & 17 & 25 \\
\hline $\mathrm{KCl}-\mathrm{Mg}, \mathrm{mg} / \mathrm{kg}$ & 50 & 103 & 66 & 400 & 60 & 92 \\
\hline $\mathrm{AL}-\mathrm{P}_{2} \mathrm{O}_{5}, \mathrm{mg} / \mathrm{kg}$ & 222 & 340 & 258 & 424 & 500 & 274 \\
\hline $\mathrm{AL}-\mathrm{K}_{2} \mathrm{O}, \mathrm{mg} / \mathrm{kg}$ & 264 & 263 & 264 & 442 & 720 & 282 \\
\hline EDTA-Cu, mg/kg & 4 & 5 & 5 & 4 & 6 & 5 \\
\hline EDTA-Zn, mg/kg & 2 & 21 & 8 & 3 & 3 & 7 \\
\hline EDTA-Mn, mg/kg & 130 & 58 & 108 & 228 & 292 & 119 \\
\hline
\end{tabular}

A talajvizsgálati átlagokat tájanként csoportosítva és az emelkedő $\mathrm{pH}(\mathrm{KCl})$ függvényében tanulmányozhatjuk a 3. táblázatban. A pH emelkedésével a 6-7 $\mathrm{pH}(\mathrm{KCl})$-tartományig nő a talajok átlagos kötöttsége, humusz \%-a, valamint az ALPK- és a KCl+EDTA-Mn tartalma az összes minta $(\mathrm{n}=206)$ és az Alföld $(\mathrm{n}=182)$ mintacsoportban egyaránt. A 7 feletti $\mathrm{pH}(\mathrm{KCl})$-tartományban, tehát a kifejezetten meszes talajok esetében, az említett mutatóknál visszaesést tapasztaltunk. Az emelkedett mésztartalom hígulást eredményezhet, ill. mérsékelheti szemmel láthatóan a mangán oldhatóságát. A dunántúli talajmintáknál a 6-7 pH(KCl)-tartományban találhatók a kötöttebb, enyhén meszes, AL-P- és AL-Na-tartalomban és oldható mangánban gazdagabb termőhelyek. Megemlítjük, hogy az Alföld 182 dohánytermő táblájából a Hevesi-homokhát 16, a Tápió-menti homokhát 6 , a Duna-Tisza köze 41, a Tiszavidék 8, míg a Vadászpatak-mente 2 db mintával szerepelt.

A 4. táblázatban az 1991. évben végzett talajvizsgálatok eredményeit tüntettük fel. A 30 alatti kötöttségü $\left(K_{A}<30\right)$ homoktalajok $(n=74)$ és a 30-40 $K_{A}$ közötti homokos vályog/vályog mechanikai összetételü $(\mathrm{n}=6)$ talajcsoport cc. $\mathrm{HNO}_{3}+\mathrm{cc}$. $\mathrm{H}_{2} \mathrm{O}_{2}$ feltárással meghatározott elemtartalmában lényeges különbség adódik. A kötöttebb, kolloidokban gazdagabb talajok átlagában a legtöbb vizsgált elem $(\mathrm{Fe}$, $\mathrm{Al}, \mathrm{Mg}, \mathrm{K}, \mathrm{P}, \mathrm{Mn}, \mathrm{S}, \mathrm{Ba}, \mathrm{Zn}, \mathrm{Cu}, \mathrm{Ni}, \mathrm{Pb}, \mathrm{Cr}$ és Co) készlete 1,5-2,5-szerese a $\mathrm{K}_{\mathrm{A}}<$ 30 talajokénak. A B-tartalomban ugyanitt 4-szeres különbség adódik, Ca- és Srtartalma viszont $20-30 \%$-kal haladja meg csupán a kolloidszegény talajokét. Nincs érdemi különbség a két talajcsoport között az As és Cd elemek terén, míg az esetenkénti $\mathrm{Cu}$-szennyezés miatt az átlagos $\mathrm{Cu}$-készlet a $\mathrm{K}_{\mathrm{A}}<30$ csoportban emelkedettebb. 
3. táblázat

Az 1990. és 1991. évi vizsgálatokba vont dohánytermő területek szántott rétegének talajvizsgálati jellemzői tájanként és a $\mathrm{pH}(\mathrm{KCl})$ függvényében (Debreceni NTÁ vizsgálatai)

\begin{tabular}{|c|c|c|c|c|c|c|c|c|}
\hline \multirow{3}{*}{$\begin{array}{c}\mathrm{pH} \\
(\mathrm{KCl})\end{array}$} & \multirow{3}{*}{$\begin{array}{c}(1) \\
\text { Minta- } \\
\text { szám } \\
(\mathrm{n})\end{array}$} & \multirow{3}{*}{$\begin{array}{c}(2) \\
\text { Kötött- } \\
\text { ség } \\
\left(\mathrm{K}_{\mathrm{A}}\right) \\
\end{array}$} & \multirow{3}{*}{$\begin{array}{c}\text { Humusz } \\
\%\end{array}$} & \multirow{3}{*}{$\begin{array}{c}\mathrm{CaCO}_{3} \\
\%\end{array}$} & \multicolumn{3}{|c|}{$\begin{array}{l}\text { Ammónium-laktát (AL) } \\
\text { oldható }\end{array}$} & \multirow{2}{*}{$\begin{array}{c}\mathrm{KCl}- \\
\text { EDTA } \\
\mathrm{Mn}\end{array}$} \\
\hline & & & & & $\mathrm{P}_{2} \mathrm{O}_{5}$ & $\mathrm{~K}_{2} \mathrm{O}$ & $\mathrm{Na}$ & \\
\hline & & & & & \multicolumn{4}{|c|}{$\mathrm{mg} / \mathrm{kg}$} \\
\hline \multicolumn{9}{|c|}{ A. Összes minta $(n=206)$} \\
\hline $3-4$ & 35 & 26 & 0,9 & 0,0 & 213 & 218 & 15 & 100 \\
\hline $4-5$ & 56 & 27 & 1,1 & 0,0 & 195 & 294 & 17 & 138 \\
\hline $5-6$ & 32 & 29 & 1,3 & 0,0 & 289 & 323 & 29 & 159 \\
\hline $6-7$ & 27 & 31 & 1,7 & 0,6 & 388 & 370 & 28 & 193 \\
\hline$>7$ & 56 & 27 & 1,2 & 5,4 & 326 & 244 & 34 & 53 \\
\hline \multicolumn{9}{|c|}{ B. Alföld $(n=182)^{*}$} \\
\hline $3-4$ & 28 & 26 & 0,8 & 0,0 & 220 & 253 & 16 & 106 \\
\hline $4-5$ & 48 & 27 & 1,2 & 0,0 & 194 & 277 & 17 & 139 \\
\hline $5-6$ & 29 & 30 & 1,3 & 0,0 & 288 & 336 & 30 & 170 \\
\hline $6-7$ & 21 & 30 & 1,8 & 0,6 & 408 & 424 & 27 & 199 \\
\hline$>7$ & 56 & 27 & 1,2 & 5,4 & 326 & 244 & 34 & 53 \\
\hline \multicolumn{9}{|c|}{ C. Ebböl Nyírség $(n=109)$} \\
\hline $3-4$ & 27 & 26 & 0,8 & 0,0 & 223 & 251 & 16 & 100 \\
\hline $4-5$ & 46 & 26 & 0,9 & 0,0 & 181 & 258 & 16 & 134 \\
\hline $5-6$ & 18 & 26 & 1,0 & 0,0 & 223 & 253 & 24 & 147 \\
\hline $6-7$ & 9 & 26 & 1,2 & 0,3 & 318 & 394 & 23 & 146 \\
\hline$>7$ & 9 & 28 & 1,3 & 2,7 & 342 & 301 & 30 & 80 \\
\hline \multicolumn{9}{|c|}{ D. Dunántúli-dombság $(n=24)$} \\
\hline $3-4$ & 8 & 26 & 1,0 & 0,0 & 179 & 105 & 11 & 98 \\
\hline $4-5$ & 7 & 26 & 1,1 & 0,0 & 211 & 412 & 16 & 112 \\
\hline $5-6$ & 3 & 25 & 1,0 & 0,0 & 300 & 200 & 15 & 56 \\
\hline $6-7$ & 6 & 34 & 1,4 & 0,6 & 317 & 182 & 28 & 172 \\
\hline \multicolumn{9}{|c|}{ E. Ebböl Somogy $(n=22)$} \\
\hline $3-4$ & 8 & 26 & 1,0 & 0,0 & 179 & 105 & 11 & 98 \\
\hline $4-5$ & 7 & 26 & 1,1 & 0,0 & 211 & 412 & 16 & 112 \\
\hline $5-6$ & 3 & 25 & 1,0 & 0,0 & 300 & 200 & 15 & 56 \\
\hline $6-7$ & 4 & 38 & 1,6 & 0,7 & 421 & 191 & 30 & 208 \\
\hline
\end{tabular}

Megjegyzés: *Alföld: Hevesi-homokhát $(\mathrm{n}=16)$, Tápió-menti homokhát $(\mathrm{n}=6)$, DunaTisza köze $(\mathrm{n}=41)$, Tisza-vidék $(\mathrm{n}=8)$, Vadász patak mentén $(\mathrm{n}=2)$

Érdeklődésre tarthat számot, hogy a fenti módon meghatározott „összes” elemtartalom hogyan viszonyul az $\mathrm{NH}_{4}$-acetát+EDTA-oldató elemtartalomhoz, ill. fordítva. A 4. táblázatban feltüntettük az „oldható” tartalmak fóátlagait és kifejeztük az „összes” \%-ában. Az így kapott oldhatósági sorrend az alábbinak adódott: $\mathrm{Ca}$ és $\mathrm{Sr}$ 74-75\%; Ba és Cu 54-57\%; Mn 32\%; Pb, Cd, Na és Co 21-25\%; S, P, K és Zn 12 $17 \%$; Mg és Ni $8-10 \%$, Fe és Al 1-2\%. Az As és Mo kevesebb, mint $1 \%$-át tudtuk oldható formában azonosítani. A Hg, Mo és Se mindkét módszerrel a kimutatható- 
KÁDÁR - GONDOLA

sági határ alatt maradt. Az átlagos B-tartalom viszont a Lakenen és Erviö módszerrel 72\%-kal többnek adódott, mert a savas-peroxidos roncsolásnál a bór veszteséget szenvedhet. A Ca és Sr nagy oldható részaránya elsősorban a karbonátmentes, ill. a kis $\mathrm{CaCO}_{3}$-tartalmú talajokra jellemzö.

\section{4. táblázat}

Az 1991. évi vizsgálatba vont dohánytermő területek szántott rétegének elemtartalma a kötöttség $\left(\mathrm{K}_{\mathrm{A}}\right)$ és az oldhatóság függvényében (MTA TAKI vizsgálatai)

\begin{tabular}{|c|c|c|c|c|c|}
\hline \multirow{2}{*}{$\begin{array}{l}(1) \\
\text { Elem } \\
\text { jele }\end{array}$} & \multicolumn{3}{|c|}{ (2) cc. $\mathrm{HNO}_{3}+$ cc. $\mathrm{H}_{2} \mathrm{O}_{2}$, összes" tartalom } & \multirow{2}{*}{$\begin{array}{c}(4) \\
\text { LE-tartalom* } \\
\text { Főátlag } \\
(\mathrm{n}=80)\end{array}$} & \multirow{2}{*}{$\begin{array}{c}\text { (4) } \\
\text { LE-oldható az } \\
\text { „összes" \%- } \\
\text { ában (n=80) }\end{array}$} \\
\hline & $\begin{array}{c}(3) \\
\text { Főátlag } \\
(\mathrm{n}=80)\end{array}$ & $\begin{array}{c}\mathrm{K}_{\mathrm{A}}<30 \\
(\mathrm{n}=74)\end{array}$ & $\begin{array}{c}\mathrm{K}_{\mathrm{A}}=30-40 \\
(\mathrm{n}=6)\end{array}$ & & \\
\hline $\mathrm{Ca}$ & 9639 & 9410 & 12475 & 7090 & 74 \\
\hline $\mathrm{Fe}$ & 6486 & 6096 & 11298 & 92 & $1-2$ \\
\hline $\mathrm{Al}$ & 3313 & 3078 & 6211 & 47 & $1-2$ \\
\hline $\mathrm{Mg}$ & 2546 & 2414 & 4176 & 210 & 8 \\
\hline $\mathrm{K}$ & 868 & 838 & 1246 & 120 & 14 \\
\hline $\mathrm{P}$ & 538 & 510 & 886 & 86 & 16 \\
\hline $\mathrm{Mn}$ & 361 & 328 & 768 & 117 & 32 \\
\hline $\mathrm{S}$ & 114 & 107 & 200 & 19 & 17 \\
\hline $\mathrm{Na}$ & 50 & 49 & 67 & 11,9 & 24 \\
\hline $\mathrm{Ba}$ & 27 & 24 & 62 & 15,5 & 57 \\
\hline $\mathrm{Zn}$ & 23 & 22 & 38 & 2,6 & 12 \\
\hline $\mathrm{Sr}$ & 22 & 22 & 27 & 16,8 & 75 \\
\hline $\mathrm{Cu}$ & 20 & 20 & 14 & 11,0 & 54 \\
\hline $\mathrm{Ni}$ & 10 & 9 & 24 & 1,0 & 10 \\
\hline $\mathrm{Pb}$ & 10 & 9 & 15 & 2,4 & 25 \\
\hline $\mathrm{Cr}$ & 6,0 & 5,5 & 12,2 & 0,03 & $<1$ \\
\hline $\mathrm{Co}$ & 3,6 & 3,3 & 7,5 & 0,76 & 21 \\
\hline As & 1,5 & 1,6 & 1,3 & $<\mathrm{KH}$ & $<1$ \\
\hline B & 0,3 & 0,2 & 0,6 & 0,47 & 172 \\
\hline $\mathrm{Cd}$ & 0,3 & 0,3 & 0,3 & 0,06 & 22 \\
\hline
\end{tabular}

Megjegyzés: *LE $=\mathrm{NH}_{4}$-acetát+EDTA oldható (LAKENEN \& ERVIÖ, 1971); LE-oldhatósági sorrend: $\mathrm{Ca}, \mathrm{Sr}$ (74-75\%); Ba, Cu (54-57\%); Mn (32\%); Pb, Cd, Na, Co (21-25\%); S, P, K, Zn (12-17\%); Mg, Ni (8-10\%); Fe, Al (1-2\%); As, Mo (<1\%); míg a B 172\%, mert a savasperoxidos roncsolásnál veszteséget szenved. A Hg, Se, Mo általában kimutatási határ $(\mathrm{KH})$ alatt maradt

Az 1991. évi adatok szerint a $K_{A}<30$ homokos termőhelyek „összes” elemkészletében is kiugró elétérések azonosíthatók. Eredményeinket a $\mathrm{pH}(\mathrm{KCl})$ függvényében az 5. táblázatban közöljük táblaszintủ vizsgálatok alapján. A pH emelkedésével lényegében a $\mathrm{Ca}, \mathrm{Mg}$ és $\mathrm{Sr}$ mutat csupán pozitív kapcsolatot. Kiugróan nagy a nyírkarászi és kerekegyházai táblák P-, Zn- és Cu-, valamint a nyírgyulaji és különösen a kécskei Cu-készlete, mely elemek már talajszennyezést tükrözhetnek. Kérdés, hogy az oldható elemtartalmak és a növényi koncentrációk mennyiben lesznek 
összhangban az itt bemutatott extrém dúsulásokkal? Tendencia jelleggel nyomon követhető, hogy a savanyú kilúgozott homokok feltalajában feldúsulhat a $\mathrm{Fe}, \mathrm{Al}$ és Mn a meszes táblák talajához képest. Figyelemre méltó, hogy az erösen elsavanyodott talajban az „összes” Mg-készlet meghaladja a Ca-készletet, pl. Ilk-Gemzse és

\section{5. táblázat}

Egyedi homok dohánytermő helyek szántott rétegének „összes” elemtartalma a pH függvényében 1991-ben (MTA TAKI vizsgálatai)

\begin{tabular}{|l|c|c|c|c|c|c|c|c|}
\hline \multirow{2}{*}{$\begin{array}{c}\text { Termöhely } \\
\text { Tegnevezése }\end{array}$} & \multirow{2}{*}{$\begin{array}{c}\mathrm{pH} \\
\text { megl) }\end{array}$} & \multicolumn{6}{c|}{ (2) cc. $\mathrm{HNO}_{3}+\mathrm{cc} . \mathrm{H}_{2} \mathrm{O}_{2}$ oldható ,összes”, $\mathrm{mg} / \mathrm{kg}$} \\
\cline { 3 - 9 } & $\mathrm{Ca}$ & $\mathrm{Mg}$ & $\mathrm{K}$ & $\mathrm{P}$ & $\mathrm{Mn}$ & $\mathrm{Na}$ & $\mathrm{Zn}$ \\
\hline Ilk-Gemzse & 3,5 & 356 & 1112 & 754 & 473 & 336 & 44 & 22 \\
Gesztréd & 4,1 & 787 & 988 & 1135 & 636 & 298 & 37 & 25 \\
Nyírgyulaj & 4,1 & 565 & 636 & 561 & 294 & 310 & 25 & 15 \\
Kécske & 4,4 & 584 & 1172 & 1071 & 497 & 407 & 48 & 38 \\
Nyírkárász & 4,5 & 1282 & 1394 & 1591 & 816 & 535 & 54 & 43 \\
Gesztréd & 5,4 & 1352 & 1421 & 1966 & 548 & 331 & 55 & 28 \\
Nagykálló & 6,4 & 2121 & 1602 & 1214 & 423 & 321 & 48 & 25 \\
Kerekegyháza & 7,3 & 6509 & 1336 & 556 & 914 & 173 & 58 & 66 \\
Kúnadacs & 7,9 & 10670 & 2266 & 380 & 653 & 134 & 30 & 15 \\
Szabadszállás & 8,1 & 46600 & 11270 & 551 & 401 & 176 & 83 & 13 \\
\hline
\end{tabular}

\begin{tabular}{|l|c|c|c|c|c|c|c|c|}
\hline \multirow{2}{*}{$\begin{array}{c}\text { Termőhely } \\
\text { megnevezése }\end{array}$} & \multirow{2}{*}{$\begin{array}{c}\mathrm{pH} \\
(\mathrm{KCl})\end{array}$} & \multicolumn{6}{c|}{ (2) $\mathrm{cc} . \mathrm{HNO}_{3}+\mathrm{cc} . \mathrm{H}_{2} \mathrm{O}_{2}$ oldható ,összes”, $\mathrm{mg} / \mathrm{kg}$} \\
\cline { 3 - 9 } & $\mathrm{Al}$ & $\mathrm{S}$ & $\mathrm{Ba}$ & $\mathrm{Sr}$ & $\mathrm{Pb}$ & $\mathrm{Ni}$ & $\mathrm{Cu}$ \\
\hline Ilk-Gemzse & 3,5 & 3371 & 61 & 16 & 5 & 12 & 10 & 5 \\
Gesztréd & 4,1 & 3380 & 64 & 24 & 7 & 8 & 8 & 6 \\
Nyírgyulaj & 4,1 & 2115 & 47 & 18 & 3 & 6 & 4 & 67 \\
Kécske & 4,4 & 3056 & 75 & 20 & 7 & 13 & 11 & 218 \\
Nyírkárász & 4,5 & 3815 & 112 & 61 & 28 & 13 & 13 & 36 \\
Gesztréd & 5,4 & 4240 & 110 & 36 & 9 & 12 & 12 & 8 \\
Nagykálló & 6,4 & 5566 & 84 & 43 & 16 & 12 & 16 & 8 \\
Kerekegyháza & 7,3 & 1395 & 175 & 13 & 18 & 8 & 4 & 222 \\
Kúnadacs & 7,9 & 1221 & 117 & 0 & 21 & 5 & 3 & 5 \\
Szabadszállás & 8,1 & 2444 & 61 & 0 & 67 & 4 & 6 & 5 \\
\hline
\end{tabular}

Megjegyzés: Termőhelyek jellemzése táblánként 2-2 átlagmintával $(\mathrm{n}=2)$

Kécske esetében 2-3-szorosan. A 7 feletti $\mathrm{pH}(\mathrm{KCl})$ esetében a helyzet fordított, a kalcium magnéziumhoz viszonyított túlsúlya 4-5-szörössé válik. Mindez részben az alapkőzettel, döntően azonban a kilúgzási viszonyokkal függ össze.

A cc. $\mathrm{HNO}_{3}+$ cc. $\mathrm{H}_{2} \mathrm{O}_{2}$ feltárás nem képes a kristályrácsokba zárt elemeket kimutatni, ill. a talaj valódi összes készletének csak egy részét, esetenként a kisebb hányadát (pl. K, Cr, Mo stb.) jellemzi. A Ca és Mg azonban jól kimutatható e módszerrel. A Mg-sók rosszabbul oldódnak, mint a Ca-sók, az erősen elsavanyodott és kilúgozott talajok feltehetően ezért kalciumban szegényedhetnek el elsősorban. A 
KÁDÁR - GONDOLA

jelenség, ill. a folyamatok mélyebb megértése további talajkémiai vizsgálatokat igényelhet.

A 6. táblázatban a homok termőhelyek oldható elemtartalma tanulmányozható a $\mathrm{pH}(\mathrm{KCl})$ függvényében üzemszintü/táblaszintủ eredmények alapján. A pH emelkedésével itt is nő a Ca-, Mg- és $\mathrm{Sr}$-mennyiség. Egyértelmúen és több nagyságrenddel ugrik meg a Na- és csaknem tizedére mérséklődik az Al-tartalom az erősen elsavanyodott termőhelyhez képest. $\mathrm{A} \mathrm{Ca} / \mathrm{Mg}$ aránya közel 10-szeressé tágul a savanyú talajokon, míg 7,3, 7,9, ill. 8,1 $\mathrm{pH}(\mathrm{KCl})$ esetén ez az arány már 17, 39, ill. kereken 60. $\mathrm{Az} \mathrm{NH}_{4}$-acetát+EDTA módszer (amint láttuk) közel egy nagyságrenddel jobban oldja a talaj Ca-vegyületeit, mint $\mathrm{Mg}$-sóit.

Itt is nyomon követhető Nyírgyulaj Cu-, valamint Kécske, Nyírkárász és Kerekegyháza talajának Zn- és Cu-szennyezettsége. Kiugró Kerekegyháza nagy oldható P-készlete, mely az üvegházi talajokét is meghaladhatja. Az is megállapítható, hogy

\section{6. táblázat}

Egyedi homok dohánytermő helyek szántott rétegének oldható elemtartalma a pH függvényében 1991-ben (MTA TAKI vizsgálatai)

\begin{tabular}{|l|c|c|c|c|c|c|c|c|}
\hline \multirow{2}{*}{$\begin{array}{c}\text { Termöhely } \\
\text { Tegnevezése }\end{array}$} & \multirow{2}{*}{$\begin{array}{c}\mathrm{pH} \\
\text { mel) }\end{array}$} & \multicolumn{6}{|c|}{ (2) $\mathrm{NH}_{4}$-acetát+EDTA oldható elemtartalom, $\mathrm{mg} / \mathrm{kg}$} \\
\cline { 3 - 9 } & & $\mathrm{Ca}$ & $\mathrm{P}_{2} \mathrm{O}_{5}$ & $\mathrm{~K}_{2} \mathrm{O}$ & $\mathrm{Zn}$ & $\mathrm{Cu}$ & $\mathrm{Mn}$ & $\mathrm{Mg}$ \\
\hline Ilk-Gemzse & 3,5 & 70 & 74 & 43 & 2,6 & 4,2 & 40 & 7 \\
Gesztréd & 4,1 & 358 & 138 & 110 & 1,8 & 0,8 & 49 & 24 \\
Nyírgyulaj & 4,1 & 193 & 65 & 64 & 0,9 & 22,3 & 48 & 22 \\
Kécske & 4,4 & 317 & 162 & 159 & 8,3 & 99,9 & 122 & 20 \\
Nyírkárász & 4,5 & 642 & 207 & 225 & 6,2 & 15,4 & 163 & 43 \\
Gesztréd & 5,4 & 783 & 114 & 413 & 2,2 & 1,8 & 119 & 122 \\
Nagykálló & 6,4 & 1613 & 60 & 86 & 1,1 & 1,5 & 76 & 90 \\
Kerekegyháza & 7,3 & 3881 & 848 & 216 & 27,2 & 144,0 & 78 & 219 \\
Kúnadacs & 7,9 & 8091 & 469 & 186 & 6,1 & 2,3 & 74 & 210 \\
Szabadszállás & 8,1 & 30860 & 45 & 62 & 0,5 & 1,2 & 93 & 517 \\
\hline
\end{tabular}

\begin{tabular}{|l|c|c|c|c|c|c|c|c|}
\hline \multirow{2}{*}{$\begin{array}{c}\text { Termöhely } \\
\text { megnevezése }\end{array}$} & $\mathrm{pH}$ & \multicolumn{6}{|c|}{ (2) $\mathrm{NH}_{4}$-acetát+EDTA oldható elemtartalom, $\mathrm{mg} / \mathrm{kg}$} \\
\cline { 4 - 9 } & $(\mathrm{KCl})$ & $\mathrm{Al}$ & $\mathrm{S}$ & $\mathrm{Na}$ & $\mathrm{Sr}$ & $\mathrm{Pb}$ & $\mathrm{Ni}$ & $\mathrm{Co}$ \\
\hline Ilk-Gemzse & 3,5 & 81 & 11 & 0,1 & 1,9 & 0,2 & 0,1 & 0,4 \\
Gesztréd & 4,1 & 100 & 7 & 0,3 & 2,7 & 0,5 & 1,1 & 0,3 \\
Nyírgyulaj & 4,1 & 61 & 24 & 1,2 & 1,3 & 0,7 & 0,2 & 0,4 \\
Kécske & 4,4 & 48 & 15 & 1,1 & 2,8 & 1,3 & 0,5 & 0,9 \\
Nyírkárász & 4,5 & 73 & 3 & 2,4 & 12,4 & 1,0 & 1,6 & 1,2 \\
Gesztréd & 5,4 & 38 & 16 & 5,1 & 3,6 & 14 & 2,2 & 0,9 \\
Nagykálló & 6,4 & 40 & 14 & 3,5 & 8,1 & 1,7 & 2,0 & 0,9 \\
Kerekegyháza & 7,3 & 22 & 35 & 11,6 & 10,0 & 4,1 & 0,5 & 0,3 \\
Kúnadacs & 7,9 & 12 & 15 & 15,4 & 15,5 & 2,3 & 0,3 & 0,2 \\
Szabadszállás & 8,1 & 13 & 21 & 30,6 & 60,7 & 1,0 & 0,3 & 0,5 \\
\hline
\end{tabular}

Megjegyzés: Termőhelyek jellemzése táblánként 2-2 átlagmintával $(\mathrm{n}=2)$ 
a dohánytermő területek nagy része foszforral és káliummal igen jól ellátott kerti talaj jelleget mutat. A talajok $\mathrm{Pb}, \mathrm{Ni}$ és Co nehézfémekkel nem szennyezettek, de rendkívül heterogén készlettel rendelkezhetnek. Így pl. a Co tekintetében 6-szoros, $\mathrm{az} \mathrm{Pb}$ és $\mathrm{Ni}$ esetében pedig 20-szoros különbségek is előfordulnak az oldható tartalmakban. Az oldható S-tartalomban is nagyságrendi szórást találtunk, amely nem mutat kapcsolatot a P-készlettel, tehát közvetlenül a szuperfoszfát-trágyázással. A S-, P-, Zn- és Cu-tartalmú növényvédő szerek rendszeres és hosszú idejü használata is befolyásoló tényező lehet a talajszennyezés létrejöttében, ill. az extrém eltérések magyarázatánál. Említhető még a folyók által múltban lerakott hordalék szerepe.

A dohánytermesztési nagytájak és dohánybeváltó körzetek megoszlását az országban az alábbi felsorolás érzékeltetheti: míg a Dunántúlt mindössze egy beváltókörzet (Nagyatád), a Duna-Tisza közét kettő (Kiskunhalas, Kiskunfélegyháza), DTiszántúlt szintén kettő (Szolnok, Jászberény), É-Magyarországot egy (Kápolna) körzet képviseli, addig K-Magyarországot öt (Vásárosnamény, Nagykálló, Nyíregyháza, Nyírbátor, Debrecen), utalva ezzel a Nyírség meghatározó szerepére a dohánytermesztésben.

A 7. táblázatban az 1990-1991. évi országos dohányökológiai felmérés termésés levélvizsgálati eredményeit tüntettük fel. A csapadékosabb 1991-ben, mint az adatokból látható, nőtt az átlagos termésszint és javult a dohánylevél minősége. Utóbbiról tanúskodik, hogy felére csökkent az összes alkaloida/nikotin-tartalom a levélben, ezzel együtt emelkedett a redukáló cukor, a világos „B” minőségi válogatási osztály aránya, a beváltási ár, valamint a ha-onkénti bevétel. Az egyes termőhelyeket tekintve a termés, beváltási ár és az összes alkaloida minimum és maximum értékei között 3-4-szeres, a ha-onkénti bevételben 6-szoros, a világos „, $\mathrm{B}$ ” válogatási osztály tekintetében 13 -szoros, míg a redukáló cukor \%-ában 20-szoros eltéréseket tapasztalhatunk.

Ami a levéltermés ásványi összetételét illeti megállapítható, hogy a kedvezőbb 1991. évben szignifikánsan mérséklődött a levelek N-, Ca-, Mg-, Mn-, Sr-, Fe-, Al-, B- és Ni-tartalma, hígulási effektus nyilvánult meg. Ezzel szemben a P-, Cr-, és Pbfelvétel nőtt, feltehetően ezen elemek jobb talajbani oldhatósága nyomán. Meg kell említeni, hogy bár a vizsgálatba vont dohánytermő táblák/gazdaságok száma változott és helye is változhatott az éveket tekintve, eloszlásuk mindkét évben reprezentatív volt. Az ,évhatásokat” ebböl adódóan mérvadónak fogadhatjuk el. Az As $(0,33 \mathrm{mg} / \mathrm{kg}), \mathrm{Hg}(0,24 \mathrm{mg} / \mathrm{kg})$ és Se $(0,46 \mathrm{mg} / \mathrm{kg})$ mindkét évben az alábbi kimutathatósági határ alatt maradt. Bizonyos termőhelyeken $0,1 \mathrm{mg} / \mathrm{kg}$ körüli kimutatási határ alatt maradt a $\mathrm{Ni}, \mathrm{Cr}, \mathrm{Pb}, \mathrm{Co}$ és Mo is (7. táblázat).

A 7. táblázat áttekintést nyújt a levéltermés ásványi elemeinek összetételéről a minimum- és maximumértékeket, valamint a variációs koefficienseket is bemutatva. Az adatok arra utalnak, hogy a dohány rendkívül tág határok között akkumulálhatja az egyes elemeket, plasztikus növény és extrém összetételekkel rendelkezhet. A minimum- és maximumtartalmak között az egyes elemeket vizsgálva az alábbi különbségek adódtak közelítően és átlagosan. A mért maximális tartalom minimumhoz viszonyított hányadosa: $\mathrm{S}$ esetében $3 ; \mathrm{Ca}, \mathrm{K}, \mathrm{P}, \mathrm{N}, \mathrm{B}, \mathrm{Pb}$ és Mo elemeknél 5-10; Al és Mg 14-17; Ca, Fe és $\mathrm{Zn} 25-30$; $\mathrm{Sr}, 51$; Cu 64; Na, Mn, Ni, Cr és Co esetén pedig már a két nagyságrendet is meghaladhatja. Az utóbbi elemek CV \%-a 
7. táblázat

Dohánytermő területek termés- és levélvizsgálati eredményei 1990. és 1991. években

\begin{tabular}{|c|c|c|c|c|c|c|c|c|}
\hline \multirow{2}{*}{\multicolumn{2}{|c|}{$\begin{array}{c}\text { Mért, ill. vizsgált } \\
\text { jellemzők }\end{array}$}} & \multirow{2}{*}{$\begin{array}{c}1990 \\
(n=126)\end{array}$} & \multirow{2}{*}{$\begin{array}{c}1991 \\
(n=80)\end{array}$} & \multirow[b]{2}{*}{$\mathrm{SzD}_{5 \%}$} & \multicolumn{4}{|c|}{$1990+1991(n=206)$} \\
\hline & & & & & $\begin{array}{c}\text { (2) } \\
\text { Átlag }\end{array}$ & Minimum & Maximum & $\begin{array}{c}\mathrm{CV} \\
\%\end{array}$ \\
\hline \multirow{6}{*}{\multicolumn{2}{|c|}{$\begin{array}{l}\text { a) Beváltási ár eFt/t } \\
\text { b) Bevétel eFt/ha } \\
\text { c) Világos ,B' osz- } \\
\text { tály } \% \\
\text { d) Redukáló cukor \% } \\
\text { e) Levéltermés, t/ha } \\
\text { f) Összes alkaloida \% }\end{array}$}} & 84 & 104 & 18 & 92 & 55 & 193 & 14 \\
\hline & & 128 & 182 & 26 & 146 & 47 & 296 & 37 \\
\hline & & 66 & 74 & 7 & 70 & 7 & 94 & 25 \\
\hline & & 11 & 18 & 5,1 & 15 & 2 & 40 & 48 \\
\hline & & 1,6 & 1,9 & 0,3 & 1,7 & 0,6 & 3,6 & 37 \\
\hline & & 2,3 & 1,1 & 0,5 & 1,7 & 0,4 & 4,3 & 53 \\
\hline $\mathrm{Ca}$ & $\%$ & 3,10 & 2,60 & 0,40 & 2,90 & 0,85 & 5,86 & 39 \\
\hline $\mathrm{K}$ & $\%$ & 2,15 & 1,89 & 0,32 & 2,05 & 0,91 & 6,21 & 37 \\
\hline $\mathrm{N}$ & $\%$ & 2,48 & 2,07 & 0,35 & 2,30 & 1,08 & 5,42 & 42 \\
\hline $\mathrm{Mg}$ & $\%$ & 0,46 & 0,24 & 0,16 & 0,38 & 0,10 & 1,69 & 52 \\
\hline $\mathrm{S}$ & $\%$ & 0,32 & 0,28 & 0,06 & 0,30 & 0,10 & 0,30 & 21 \\
\hline $\mathrm{P}$ & $\%$ & 0,17 & 0,20 & 0,64 & 0,18 & 0,06 & 0,35 & 24 \\
\hline $\mathrm{Mn}$ & $\mathrm{mg} / \mathrm{kg}$ & 314 & 172 & 92 & 257 & 30 & 3437 & 167 \\
\hline $\mathrm{Sr}$ & $\mathrm{mg} / \mathrm{kg}$ & 387 & 159 & 165 & 299 & 27 & 1373 & 86 \\
\hline $\mathrm{Fe}$ & $\mathrm{mg} / \mathrm{kg}$ & 264 & 193 & 72 & 236 & 60 & 1704 & 76 \\
\hline $\mathrm{Al}$ & $\mathrm{mg} / \mathrm{kg}$ & 146 & 114 & 34 & 133 & 41 & 570 & 61 \\
\hline $\mathrm{Na}$ & $\mathrm{mg} / \mathrm{kg}$ & 100 & 109 & 44 & 103 & 12 & 1363 & 109 \\
\hline $\mathrm{Ba}$ & $\mathrm{mg} / \mathrm{kg}$ & 38 & 37 & 12 & 38 & 12 & 109 & 46 \\
\hline $\mathrm{Zn}$ & $\mathrm{mg} / \mathrm{kg}$ & 34 & 36 & 8 & 37 & 8 & 209 & 73 \\
\hline B & $\mathrm{mg} / \mathrm{kg}$ & 27 & 17 & 6 & 23 & 7 & 60 & 43 \\
\hline $\mathrm{Cu}$ & $\mathrm{mg} / \mathrm{kg}$ & 15 & 12 & 4 & 13 & 2 & 129 & 144 \\
\hline $\mathrm{Ni}$ & $\mathrm{mg} / \mathrm{kg}$ & 2,73 & 2,09 & 0,38 & 2,47 & $<\mathrm{KH}$ & 16 & 104 \\
\hline $\mathrm{Cd}$ & $\mathrm{mg} / \mathrm{kg}$ & 1,07 & 1,15 & 0,22 & 1,12 & 0,2 & 5 & 64 \\
\hline $\mathrm{Cr}$ & $\mathrm{mg} / \mathrm{kg}$ & 0,57 & 1,03 & 0,36 & 0,68 & $<\mathrm{KH}$ & 21 & 223 \\
\hline $\mathrm{Pb}$ & $\mathrm{mg} / \mathrm{kg}$ & 0,38 & 1,03 & 0,56 & 0,65 & $<\mathrm{KH}$ & 9 & 172 \\
\hline Co & $\mathrm{mg} / \mathrm{kg}$ & 0,28 & 0,20 & 0,09 & 0,25 & $<\mathrm{KH}$ & 7 & 250 \\
\hline Mo & $\mathrm{mg} / \mathrm{kg}$ & 0,10 & 0,22 & 0,24 & 0,15 & $<\mathrm{KH}$ & 1 & 280 \\
\hline
\end{tabular}

Megjegyzés: A kritikus június + július havi csapadékösszeg 1990-ben 99 mm, 1991-ben 166 $\mathrm{mm}$. Az As, Hg, Se mindkét évben a $0,1 \mathrm{mg} / \mathrm{kg}$ kimutatási határ $(\mathrm{KH})$ alatt. $\mathrm{KH}: \mathrm{Pb} 0,53$; Se 0,46; As 0,33; Hg 0,24; Ni 0,17; Cr 0,14; Mo és Co 0,08; Cd 0,05 mg/kg sz.a. A pH 1990ben 5,6 ; 1991-ben 5,7

104-280 közöttinek adódott. Az évek ismétlésül szolgáltak az $\mathrm{SzD}_{5 \%}$-értékek számításánál.

CHOUTEAU és FAUCONNIER (1988) szerint a száraz dohánylevél optimális elemtartalma a következő lehet: $2,5-3,5 \% \mathrm{~K} ; 2,0-5,0 \% \mathrm{~N} ; 1,8-3,6 \% \mathrm{Ca} ; 0,3-0,8 \% \mathrm{Mg}$; 0,2-0,4\% P és S; 50-80 mg/kg Mn; 20-80 mg/kg Zn; 20-40 mg B; $15-21 \mathrm{mg} / \mathrm{kg}$ $\mathrm{Cu}$. E mellett kívánatos, hogy a szennyező nehézfémek tartalma (mint a Ni, Cd, $\mathrm{Cr}$, 


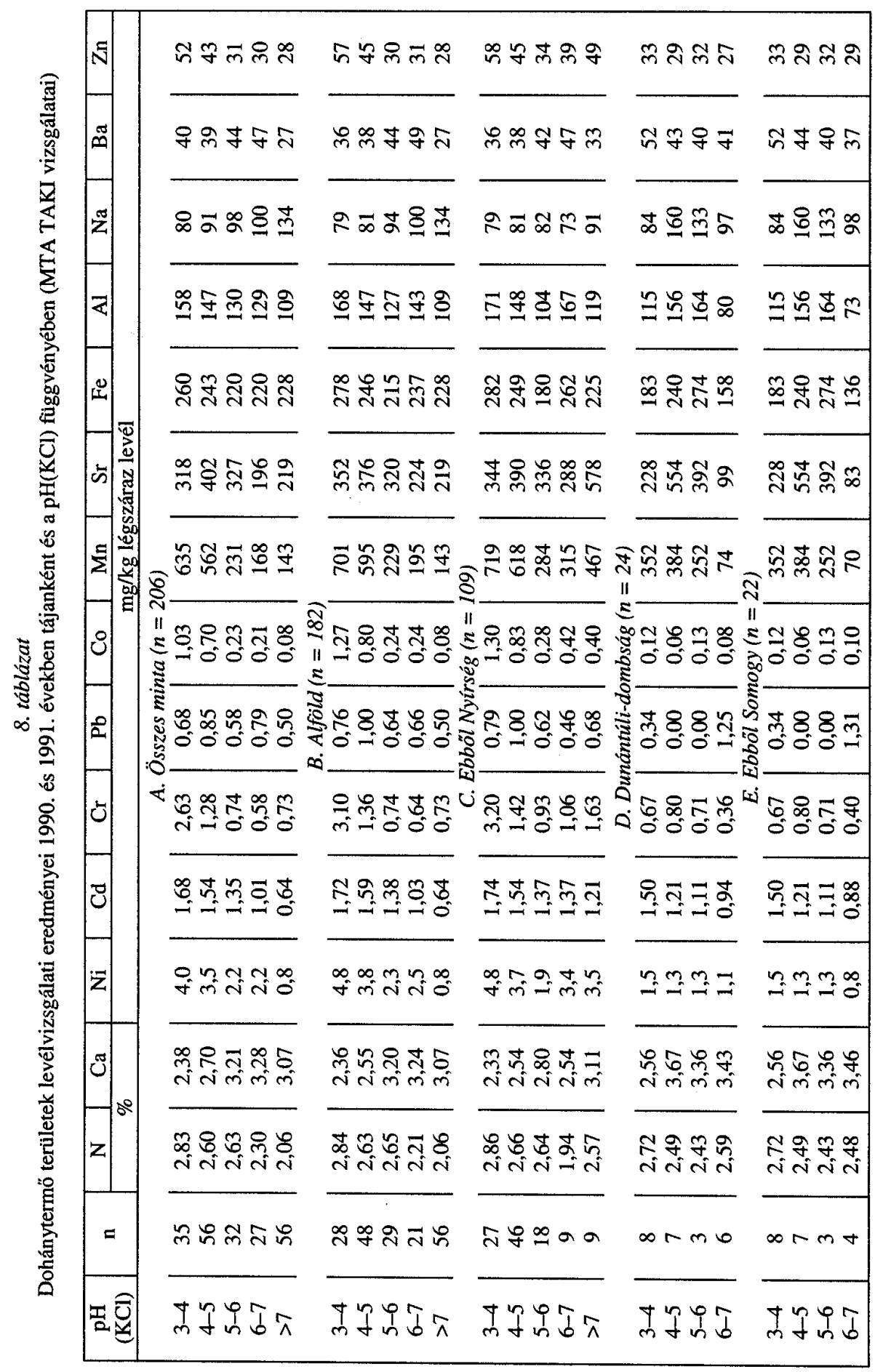


$\mathrm{Pb}$, Co és Mo) $0,1-0,2 \mathrm{mg} / \mathrm{kg}$ alatt maradjon. A dohány tápláltsági állapotát vizsgálva 1991-1992. években Magyarországon látható, hogy egyaránt előfordultak Ca, $\mathrm{K}, \mathrm{N}, \mathrm{Mg}, \mathrm{S}$ és $\mathrm{P}$ makroelemekben, valamint $\mathrm{Mn}, \mathrm{B}, \mathrm{Zn}$ és $\mathrm{Cu}$ mikroelemekben egyaránt kifejezetten hiányos és túlsúlyos termőhelyek. Komoly nehézfémszennyezés állhat fenn egyes üzemekben a $\mathrm{Cu}, \mathrm{Zn}, \mathrm{Ni}, \mathrm{Cd}, \mathrm{Cr}, \mathrm{Pb}$ és Co elemek terén (7. táblázat).

A 8. táblázatban a $\mathrm{N}, \mathrm{Ca}$, valamint néhány nehézfém levélben mért tartalmát közöljük nagytájanként és a talaj-pH függvényében. Általában megfigyelhető, hogy a $\mathrm{pH}(\mathrm{KCl})$-tartományok emelkedésével mérséklődik az átlagos N-készlet, emelkedik a $\mathrm{Ca} \%$, valamint csökken a $\mathrm{Ni}, \mathrm{Cd}, \mathrm{Cr}, \mathrm{Pb}$ és Co levélben mért tartalma. Különösen a 7 feletti $\mathrm{pH}(\mathrm{KCl})$-tartományban, a meszes termőhelyeken, esik drasztikusan le a levélbe épült Ni-, Cd- és Co-mennyiség. Meg kell említeni, hogy a levéltermés, összes alkaloida, redukáló cukor, világos „B” válogatási osztály, beváltási ár, ill. bevételi mutatókban ilyen egyértelmü trendek, változások nem jelentkeztek. Az elemtartalmakban megfigyelt trendek viszont meggyőzők. A minták száma ugyan nem azonos az egyes $\mathrm{pH}$-tartományokban, de elégséges lehet a stabilabb átlag jellemzésére különösen az összes minta, ill. Alföld mintaszámait figyelembe véve. Az átlagos pH(KCl) 1990-ben $(5,6)$ és 1991-ben $(5,7)$ közelálló volt, szignifikánsan nem tért el.

A pH( $\mathrm{KCl})$ emelkedése egyéb levélben mért elemek beépülését is befolyásolta. A Mn-tartalom az Alföldön pl. 1/5-ére zuhant a meszes termőhelyek átlagában az erősen savanyú termőhelyekhez képest. A Nyírségben a semleges körüli és meszes talajok száma erősen lecsökken, a kevés számú dunántúli termőhely sem teszi lehetővé a megbízható trendek nyomon követését. Az összes minta, ill. az Alföld mintaanyaga alapján a trendek azonban arra utalnak, hogy enyhén mérséklődhet a $\mathrm{Fe}$ - és Al-, valamint kifejezettebben a Zn-felvétel, míg a Na-tartalom nőhet a pH-val (8. táblázat).

Végül a bizonyos tekintetben közelálló, vagy egynemü homok termőhelyeket, táblasoros levélvizsgálati adatokat mutatunk be a $\mathrm{pH}(\mathrm{KCl})$ függvényében a 9. táblázatban. Látható, hogy a redukáló cukor, alkaloida, összes N, Ca, K, Mg, P és S\%-ok egyértelmű és meggyőző változást nem jeleznek. Csökkenő trendet tükröz a Mn, $\mathrm{Sr}$, $\mathrm{Fe}, \mathrm{Al}$ és Ba elemek levélbeni mennyisége a meszes termőhelyek felé haladva. Végül egy nagyságrendi változást okoz a $\mathrm{pH}$ emelkedése a $\mathrm{Cd}, \mathrm{Cr}, \mathrm{Co}, \mathrm{Ni}$ és $\mathrm{Pb}$ elemek felvételében. Meszes talajokon fejlődött dohány leveleiben a $\mathrm{Co}$, Ni és $\mathrm{Pb}$ nehézfémek már a kimutatási határ alatt voltak. Környezet- és humán-egészségügyi szempontból is szükségessé válhat tehát és javasolható az erősen savanyú termőhelyek, táblák meszezése.

Nem a talaj-pH függvényében, némely dohánytermő talaj vagy tábla $\mathrm{Zn}$ - és $\mathrm{Cu}$ szennyezettsége nyomon követhető. Így pl. a dohánylevél Zn-tartalmában emelkedést fordult elő különösen Nyírgyulaj, Kécske, Kerekegyháza, míg a Cu-tartalom kiugró Ilk-Gemzse, Nyírgyulaj, Nyírkárász, Kerekegyháza, Kunadacs termőhelyeken. Az említett termőhelyek $\mathrm{Cu}$ - és $\mathrm{Zn}$-szennyezettségét részben az $\mathrm{NH}_{4}$ acetát+EDTA-oldható talajvizsgálati eredmények is jelezték. Összességében azonban általában nem találtunk korrelációt a növényi elemtartalom és a talajvizsgálati adatok között. Sem az „„̈sszes”, sem a NH${ }_{4}$-acetát+EDTA-oldható elemkészlet nem 
9. táblázat

Egyedi homok dohánytermő helyek levélvizsgálati eredményei a pH függvényében 1991-ben

\begin{tabular}{|l|c|c|c|c|c|c|c|c|}
\hline \multirow{2}{*}{$\begin{array}{c}\text { Termöhely } \\
\text { megnevezése }\end{array}$} & $\begin{array}{c}\mathrm{pH} \\
(\mathrm{KCl})\end{array}$ & $\begin{array}{c}(2) \\
\text { Red. } \\
\text { cukor }\end{array}$ & $\begin{array}{c}\text { Összes } \\
\mathrm{N}\end{array}$ & $\begin{array}{c}(4) \\
\text { Alkaloida }\end{array}$ & $\mathrm{Ca}$ & $\mathrm{K}$ & $\mathrm{Mg}$ & $\mathrm{S}$ \\
\cline { 3 - 9 } & & \multicolumn{7}{|c|}{$\%$} \\
\hline Ilk-Gemzse & 3,5 & 19 & 2,73 & 0,98 & 3,46 & 2,55 & 0,33 & 0,37 \\
Gesztréd & 4,1 & 16 & 1,97 & 0,91 & 2,14 & 1,71 & 0,15 & 0,21 \\
Nyírgyulaj & 4,1 & 23 & 1,89 & 1,25 & 1,44 & 1,17 & 0,05 & 0,21 \\
Kécske & 4,4 & 10 & 2,43 & 1,64 & 2,17 & 2,40 & 0,19 & 0,55 \\
Nyírkárász & 4,5 & 18 & 2,04 & 0,70 & 2,46 & 1,88 & 0,24 & 0,32 \\
Gesztréd & 5,4 & 16 & 2,15 & 1,28 & 2,98 & 2,09 & 0,20 & 0,36 \\
Nagykálló & 6,4 & 18 & 2,00 & 0,94 & 2,31 & 1,94 & 0,29 & 0,23 \\
Kerekegyháza & 7,3 & 13 & 1,41 & 0,94 & 2,90 & 1,49 & 0,16 & 0,22 \\
Kúnadacs & 7,9 & 20 & 1,46 & 1,91 & 2,51 & 2,01 & 0,33 & 0,39 \\
Szabadszállás & 8,1 & 15 & 1,61 & 2,07 & 2,94 & 1,37 & 0,20 & 0,29 \\
\hline
\end{tabular}

\begin{tabular}{|l|c|c|c|c|c|c|c|c|}
\hline \multicolumn{1}{c|}{$\begin{array}{c}(1) \\
\text { Termöhely } \\
\text { megnevezése }\end{array}$} & $\mathrm{pH}$ & $\mathrm{Mn}$ & $\mathrm{Sr}$ & $\mathrm{Fe}$ & $\mathrm{Al}$ & $\mathrm{Na}$ & $\mathrm{Ba}$ & $\mathrm{Zn}$ \\
\cline { 3 - 9 } & $(\mathrm{KCl})$ & \multicolumn{7}{|c|}{$\mathrm{mg} / \mathrm{kg}$} \\
Ilk-Gemzse & 3,5 & 274 & 252 & 699 & 377 & 129 & 109 & 29 \\
Gesztréd & 4,1 & 291 & 152 & 380 & 200 & 91 & 50 & 14 \\
Nyírgyulaj & 4,1 & 249 & 180 & 196 & 110 & 40 & 39 & 82 \\
Kécske & 4,4 & 473 & 247 & 182 & 108 & 110 & 35 & 54 \\
Nyírkárász & 4,5 & 151 & 203 & 189 & 103 & 86 & 42 & 16 \\
Gesztréd & 5,4 & 127 & 206 & 477 & 235 & 91 & 46 & 30 \\
Nagykálló & 6,4 & 521 & 191 & 485 & 261 & 97 & 69 & 14 \\
Kerekegyháza & 7,3 & 52 & 63 & 154 & 129 & 809 & 19 & 41 \\
Kúnadacs & 7,9 & 40 & 108 & 126 & 71 & 104 & 19 & 23 \\
Szabadszállás & 8,1 & 108 & 84 & 172 & 95 & 120 & 20 & 22 \\
\hline
\end{tabular}

\begin{tabular}{|l|c|c|c|c|c|c|c|c|}
\hline \multicolumn{1}{c|}{$\begin{array}{c}(1) \\
\text { Termőhely } \\
\text { megnevezése }\end{array}$} & $\mathrm{pH}$ & $\mathrm{P}$ & $\mathrm{Cu}$ & $\mathrm{Ni}$ & $\mathrm{Cd}$ & $\mathrm{Cr}$ & $\mathrm{Pb}$ & $\mathrm{Co}$ \\
\cline { 4 - 9 } & & $\mathrm{KCl})$ & $\%$ & \multicolumn{7}{|c|}{$\mathrm{mg} / \mathrm{kg}$} \\
\hline Ilk-Gemzse & 3,5 & 0,18 & 32 & 7,0 & 2,48 & 3,11 & 2,28 & 0,44 \\
Gesztréd & 4,1 & 0,19 & 4 & 5,5 & 1,05 & 1,58 & 1,54 & 0,42 \\
Nyírgyulaj & 4,1 & 0,15 & 14 & 1,8 & 1,53 & 0,35 & 4,87 & 0,01 \\
Kécske & 4,4 & 0,17 & 4 & 1,8 & 1,42 & 0,50 & 3,04 & 0,34 \\
Nyírkárász & 4,5 & 0,15 & 12 & 4,7 & 2,79 & 0,41 & 1,18 & 0,00 \\
Gesztréd & 5,4 & 0,24 & 5 & 2,8 & 1,26 & 3,13 & 2,89 & 0,31 \\
Nagykálló & 6,4 & 0,16 & 5 & 9,70 & 2,49 & 1,61 & 1,84 & 0,91 \\
Kerekegyháza & 7,3 & 0,23 & 15 & 0,08 & 0,24 & 0,74 & 0,00 & 0,16 \\
Kúnadacs & 7,9 & 0,19 & 16 & $<\mathrm{KH}$ & 0,22 & 0,18 & $<\mathrm{KH}$ & $<\mathrm{KH}$ \\
Szabadszállás & 8,1 & 0,20 & 3 & $<\mathrm{KH}$ & 0,36 & 0,29 & $<\mathrm{KH}$ & $<\mathrm{KH}$ \\
\hline
\end{tabular}

Megjegyzés: Termőhelyek jellemzése táblánként 2-2 átlagmintával $(\mathrm{n}=2)$ 
mutatott pl. szignifikáns kapcsolatot a levélben mért elemtartalommal. A talajvizsgálati határértékeket ezért elsősorban a pH függvényében kell megállapítani a $\mathrm{Fe}$, $\mathrm{Mn}, \mathrm{Al}, \mathrm{Sr}$ és Ba, ill. különösen a $\mathrm{Zn}, \mathrm{Cd}, \mathrm{Cr}$, Co, Ni és Pb nehézfémek/szennyezök esetében.

\section{Összefoglalás}

Az 1990. és 1991. évi dohányökológiai felmérésbe összesen 206 táblát, illetve parcellát vontunk be, amelyeken Virginia típusú dohányt termesztettek. A gazdaságok véletlenszerüen lettek kiválasztva és eloszlásuk arányos volt a Virginia dohány termőterületével régióként és országosan is. A talajmintákat a mütrágyázás/kiültetés előtt vettük a szántott rétegből. A táblánként gyüjtött 2-2 átlagminta minimum 1010 pontminta összekeveréséből készült. A levélmintákat a „B” válogatási osztály képviselte. Az átlagmintákat a beváltó-üzemi szakember vette értékesítéskor, a légszáraz levéltermés megállapításakor. A talajminták alapvizsgálatát a Debreceni NTÁ végezte, majd az MTA TAKI határozta meg a cc. $\mathrm{HNO}_{3}+$ cc. $\mathrm{H}_{2} \mathrm{O}_{2}$ feltárásából az „összes”, valamint az $\mathrm{NH}_{4}$-acetát+EDTA-oldható elemtartalmakat ICP technikát alkalmazva. A levélminták $\mathrm{N}$ - és ipari minőségvizsgálata a szokásos módszerekkel a Dohánykutató Intézetben, míg az ásványi összetételt a cc. $\mathrm{HNO}_{3}+\mathrm{cc} \cdot \mathrm{H}_{2} \mathrm{O}_{2}$ roncsolást követően az MTA TAKI laboratóriuma állapította meg szintén ICP technika segítségével. A főbb megállapítások:

- A dohánytermő talajok tulajdonságai rendkívüli mértékben és széles sávban változtak ( $\mathrm{pH}, \mathrm{CaCO}_{3}$, humusz, kötöttség, makro- és mikroelem-tartalom). A homok termőhelyek aránya $91 \%$-ot tett ki, $63 \%$ savanyú, ill. 28\% meszes termőhelylyel.

- A pH(KCl) emelkedésével a 6-7 pH-tartományig nőtt a talajok kötöttsége, humusz- és oldható P-, K- és Mn-tartalma. A meszes tartományban e mutatók viszszaestek. A kötött talajok „összes” elemkészlete is nagyobb általában, kivételt a $\mathrm{Cu}$, $\mathrm{Zn}, \mathrm{Cd}$ és As képezhet. A homok termőhelyek egy része $\mathrm{Cu}$ - és $\mathrm{Zn}$-elemdúsulást/ szennyezést mutatott.

- A cc. $\mathrm{HNO}_{3}+$ cc. $\mathrm{H}_{2} \mathrm{O}_{2}$ feltárásából meghatározott „összes” elemkészletből a Ca és Sr 74-75\%-a; a Ba és Cu 54-57\%-a, a Mn 32\%-a; az Pb, Cd, Na és Co 21$25 \%$-a; a S, P, K és Zn 12-17\%-a, a Mg és Ni 8-10\%-a; a Fe és Al 1-2\%-a; az As és Mo $<1 \%$-a volt kimutatható az $\mathrm{NH}_{4}$-acetát+EDTA módszerrel. Az átlagos Btartalom oldható készlete meghaladta az „összes” tartalmat, a savas-peroxidos roncsolásnál a bór veszteséget szenvedhetett.

- Erősen kilúgozott savanyú talajokban az „összes” Mg-tartalom 2-3-szorosan haladta meg a Ca-tartalmat, míg meszes termőhelyeken ez a tendencia megfordult. Savanyú talajaink elsősorban a kilúgozásnak kevésbé ellenálló kalciumban szegényednek. Az oldható Ca-mennyiség ezzel szemben már erősen savanyú talajban is 10-szerese az oldható Mg-nak, míg a meszes termőhelyeken 40-60-szorosára ugrik. $\mathrm{Az} \mathrm{NH} \mathrm{N}_{4}$-acetát+EDTA módszer tehát közel egy nagyságrenddel jobban oldhatja a talaj Ca-vegyületeit, mint $\mathrm{Mg}$-sóit.

- A dohánytermő talajok nagyobb része oldható foszforral és káliummal igen jól ellátott kerti talaj jelleget mutatott. A nehézfémek közül $\mathrm{Pb}$, Ni és Co elemekkel 
nem szennyezettek, de heterogének. A Co 6-szoros, az $\mathrm{Pb}$ és Ni 20-szoros eltéréseket jelzett az oldható elemkészletben. A P, S, Cu és Zn elemtartalmak dúsulására a növényvédő szerek rendszeres és hosszúidejü használatával okozott talajszennyezés is magyarázatul szolgálhat. $\mathrm{A} \mathrm{Cu}$ - és $\mathrm{Zn}$-szennyeződést a levélminták is tükrözték.

- A kedvező csapadékosabb évben nőtt a levéltermés és javult a minősége. Az ásványi összetételt tekintve a $\mathrm{P}, \mathrm{Cr}$ és Pb kivételével általában a legtöbb vizsgált elem tartalma mérséklödött. A talaj-pH emelkedésével csökkent a levél Mn-, Sr-, Fe-, Al-, Ba- és $\mathrm{Zn}$-tartalma, különösen pedig a $\mathrm{Cd}, \mathrm{Cr}$, $\mathrm{Co}$, Ni és $\mathrm{Pb}$ nehézfémek beépülése. Az erősen savanyú talajok meszezése humán-egészségügyi szempontból is ajánlható.

- A talajvizsgálati adatok és a növényi összetétel, az extrém $\mathrm{Zn}$ - és $\mathrm{Cu}$ szennyezéstől eltekintve, nem mutatott szignifikáns kapcsolatot. A talajvizsgálati határértékeket elsősorban a növényi felvételt meghatározó $\mathrm{pH}$ függvényében kell megállapítani a $\mathrm{Zn}, \mathrm{Cd}, \mathrm{Cr}, \mathrm{Co}, \mathrm{Ni}$ és $\mathrm{Pb}$ nehézfém-szennyezőkre. $\mathrm{Az} \mathrm{Pb}$ és $\mathrm{Cr}$ beépülése a csapadék mennyiségével is pozitív összefüggést jelzett.

Kulcsszavak: dohánytermő körzetek, minőség, levélanalízis, talajvizsgálat

\section{Irodalom}

BARANYAi F., FEKETE A. \& KovÁCS I., 1987. A magyarországi talajtápanyag vizsgálatok eredményei. Mezőgazdasági Kiadó. Budapest.

BECKER-DillingEN, J., 1934. Handbuch der Ernährung der landwirtschaflichen Nutzpflanzen. Paul Parey Verlag. Berlin.

BELL, P. F. et al., 1988. Residual effects of land applied municipal sludge on tobacco. I. Effects on heavy metal concentrations in soils and plants. Tobacco Sci. 32. 33-38.

Borsos J. (szerk.), 1976. A dohány nagyüzemi termesztése. Mezőgazdasági Kiadó. Budapest.

Chouteau, J. \& Fauconnier, D., 1988. Fertilizing for high quality and yield. Tobacco. IPI Bulletin $\mathrm{N}^{\circ} 11$. Bern, Switzerland.

CogBiLl, E. C. \& HobBS, M. E., 1957. Transfer of metallic constituents of cigarettes to the main-stream smoke. Tobacco Sci. 1. 68-73.

CSERHÁTI S., 1900. Általános és különleges növénytermelés. Czeh Sándor-féle Könyvnyomda. Magyar-Óvár.

DiTZ, H., 1867. A magyar mezőgazdaság. (Szerk.: KÁDÁR I.) MTA TAKI. Budapest, 1993.

Gething, P. A., 1990. Potash Facts. Intern. Potash Inst. Bern, Switzerland.

GONDOLA I., 1988. Az ökológiai tényezők és a genotípus szerepe a Virginia dohányok NPK tartalmának változékonyságában. Növénytermelés. 37. 409-419.

GoNDOLA I., 1989. Összefüggés a Virginia dohányok hozamai és minőségi jellemzői között a N-mütrágyázás függvényében. Növénytermelés. 38. 241-251.

GONDOLA I., 1990. Szárazanyag-felhalmozás és tápelem-dinamikai vizsgálatok Virginia típusú dohánynövényen. Agrokémia és Talajtan. 39. 48-58.

GONDOLA, I. \& KÁDÁR, I., 1994-1995. Heavy metal content of flue-cured tobacco leaf in different growing regions of Hungary. Acta Agron. Hung. 43. 243-251. 
KÁDÁR I., 2006. A dohány ásványi táplálása. Növénytermelés. (Megjelenés alatt).

KÁDÁR I. \& SZEMES I., 1994. A nyírlugosi tartamkísérlet 30 éve. MTA TAKI. Budapest.

LAKANEN, E. \& ERVIÖ, R., 1971. A comparison of eight extractants for the determination of plant available microelements in soils. Acta Agr. Fenn. 123. 223-232.

MÉM NAK, 1978. Talajmintavételi módszer a talaj-tápanyagtartalom vizsgálatához. MÉM Növényvédelmi és Agrokémiai Központ. Budapest.

Módszerkönyv, 1968. A Dohánykutató és Fejlesztő Intézet laboratóriumi módszereinek leírása. Dohánykutató és Fejlesztő Intézet. Debrecen.

PRJANiSNYIKOV, D. N., 1965. Izbrannüe Szocsinenija. Tom II. Csasztnoe Zemledelie. Izd. „Kolosz”. Moszkva.

Usherwood, N. R., 1985. The role of K in crop quality. In.: Potassium in Agriculture. (Ed.: Munson, R. D.) 489-513. ASA, CSSA, SSA Publ. Madison, Wisc.

Érkezett: 2007. február 9. 


\title{
Pedological and agrochemical survey of tobacco-growing areas in 1990 and 1991
}

\author{
I. KÁDÁR and I. GONDOLA
}

Research Institute for Soil Science and Agricultural Chemistry (RISSAC) of the Hungarian Academy of Sciences, Budapest and Agricultural Research Centre, University of Debrecen, Nyíregyháza (Hungary)

\section{Summary}

A total of 206 fields or plots in which Virginia tobacco was grown were included in an ecological survey on tobacco in 1990 and 1991. The farms were chosen randomly and their distribution was proportional to the area sown to Virginia tobacco in each region and on a national scale. Soil samples were taken from the ploughed layer prior to mineral fertilization and planting. The two mean samples collected from each field were the result of mixing samples taken from at least 10 points. The leaves sampled were of grade B quality. These mean samples were taken for the determination of air-dry leaf yield when the crop was purchased. Basic analysis of the soil samples was carried out by the Phytosanitary and Soil Protection Station in Debrecen, while the "total" and $\mathrm{NH}_{4}$-acetate + EDTA-soluble element contents were determined after digestion with cc. $\mathrm{HNO}_{3}+$ cc. $\mathrm{H}_{2} \mathrm{O}_{2}$ using the ICP technique at RISSAC. The $\mathrm{N}$ content and industrial quality of the leaf samples were analysed using standard methods in the Tobacco Research Institute, while the mineral composition was analysed after digestion with cc. $\mathrm{HNO}_{3}+$ cc. $\mathrm{H}_{2} \mathrm{O}_{2}$ using the ICP technique at RISSAC. The main conclusions are as follows:

- The properties ( $\mathrm{pH}, \mathrm{CaCO}_{3}$, humus, plasticity, macro- and microelement contents) of the soils used to grow tobacco varied widely. Sandy locations made up $91 \%$ of the total, including $63 \%$ acidic and $28 \%$ calcareous soils.

- As the $\mathrm{pH}_{(\mathrm{KCl})}$ rose there was a corresponding rise in the heaviness of the soil and in the humus and soluble $\mathrm{P}, \mathrm{K}$ and $\mathrm{Mn}$ contents up to $\mathrm{pH}$ 6-7. These parameters declined again for alkaline soils. The "total" element content of heavy soils was generally higher, with the exception of $\mathrm{Cu}, \mathrm{Zn}, \mathrm{Cd}$ and As. Some of the sandy locations exhibited $\mathrm{Cu}$ and $\mathrm{Zn}$ accumulation/contamination.

- Of the "total" element contents determined after digestion with cc. $\mathrm{HNO}_{3}+$ cc. $\mathrm{H}_{2} \mathrm{O}_{2}, 74-75 \%$ of the $\mathrm{Ca}$ and $\mathrm{Sr}, 54-57 \%$ of the $\mathrm{Ba}$ and $\mathrm{Cu}, 32 \%$ of the $\mathrm{Mn}, 21-25 \%$ of the $\mathrm{Pb}, \mathrm{Cd}, \mathrm{Na}$ and $\mathrm{Co}, 12-17 \%$ of the $\mathrm{S}, \mathrm{P}, \mathrm{K}$ and $\mathrm{Zn}, 8-10 \%$ of the $\mathrm{Mg}$ and $\mathrm{Ni}, 1-2 \%$ of the $\mathrm{Fe}$ and $\mathrm{Al}$ and $<1 \%$ of the As and Mo could be detected with the $\mathrm{NH}_{4}$-acetate + EDTA method. The mean soluble B content exceeded the "total" content, indicating a loss of boron during acid-peroxide digestion.

- In heavily leached acidic soils the "total" Mg content was 2-3 times greater than the $\mathrm{Ca}$ content, while in calcareous locations the opposite was found. Acidic soils in Hungary are particularly poor in $\mathrm{Ca}$, which is prone to leaching. By contrast the soluble $\mathrm{Ca}$ content was ten times that of soluble $\mathrm{Mg}$ even in strongly acidic soil, and was 40-60 times as great in calcareous soil. This indicates that the dissolution of soil $\mathrm{Ca}$ compounds by $\mathrm{NH}_{4}$-acetate + EDTA is an order of magnitude greater than that of $\mathrm{Mg}$ salts. 
- The majority of tobacco-growing soils are well supplied with available phosphorus and potassium. Among the heavy metals, they were not contaminated with $\mathrm{Pb}, \mathrm{Ni}$ or $\mathrm{Co}$, but were heterogeneous. Deviations were as much as 6 times for $\mathrm{Co}$ and 20 times for $\mathrm{Pb}$ and $\mathrm{Ni}$. The accumulation of $\mathrm{P}, \mathrm{S}, \mathrm{Cu}$ and $\mathrm{Zn}$ could be attributed to soil pollution caused by the regular application of plant protection agents over long periods. The $\mathrm{Cu}$ and $\mathrm{Zn}$ contamination was also reflected in the leaf samples.

- In the wetter of the two years the leaf yield was higher and of better quality. With the exception of $\mathrm{P}, \mathrm{Cr}$ and $\mathrm{Pb}$, the contents of the other elements analysed were lower. Due to a rise in the soil $\mathrm{pH}$ there was a drop in the $\mathrm{Mn}, \mathrm{Sr}, \mathrm{Fe}, \mathrm{Al}, \mathrm{Ba}$ and $\mathrm{Zn}$ contents of the leaves, and an even greater reduction in the incorporation of the heavy metals $\mathrm{Cd}$, $\mathrm{Cr}, \mathrm{Co}, \mathrm{Ni}$ and $\mathrm{Pb}$. The liming of strongly acidic soils is thus recommended for human health reasons.

- Apart from the extreme $\mathrm{Zn}$ and $\mathrm{Cu}$ contamination, there was no significant relationship between the soil analytical data and the plant element composition. Limit values for soil analysis should be determined as a function of $\mathrm{pH}$ for the heavy metal pollutants $\mathrm{Zn}, \mathrm{Cd}, \mathrm{Cr}, \mathrm{Co}, \mathrm{Ni}$ and $\mathrm{Pb}$, as this influences plant uptake. The incorporation of $\mathrm{Pb}$ and $\mathrm{Cr}$ also exhibited a positive correlation with rainfall quantities.

Table 1. Soil analytical data for the ploughed layer of the tobacco-growing areas surveyed in 1990 and 1991. (1) Soil parameter and units. a) Humus \%; b) Upper limit of plasticity according to Arany, $\mathrm{K}_{\mathrm{A}}$. (2) Minimum value. (3) Maximum value. (4) Mean.

Table 2. Soil analytical data for the ploughed layer of the tobacco-growing areas surveyed in 1990 and 1991 according to soil types. (1): see Table 1. (2) Acidic. (3) Calcareous. (4) Total. (5) Sandy soil. (6) Heavy soil. (7) Peat soil. (8) All locations.

Table 3. Soil analytical data for the ploughed layer of the tobacco-growing areas surveyed in 1990 and 1991 in various regions and as a function of $\mathrm{pH}(\mathrm{KCl})$. (1) Sample number. (2) Upper limit of plasticity according to Arany. A. All samples. B. Great Hungarian Plain. C. Nyírség region of the Great Hungarian Plain. D. Hills of Transdanubia. E. Somogy region of the hills of Transdanubia.

Table 4. Element contents of the ploughed layer of the tobacco-growing areas surveyed in 1991 as a function of plasticity $\left(\mathrm{K}_{\mathrm{A}}\right)$ and solubility. (1) Element symbol. (2) "Total" content after digestion with cc. $\mathrm{HNO}_{3}+$ cc. $\mathrm{H}_{2} \mathrm{O}_{2}$. (3) Grand mean. (4) LE content, grand mean. (5) LE-soluble as a \% of "total". Note: $\mathrm{LE}=\mathrm{NH}_{4}$-acetate + EDTA-soluble (LAKANEN \& ERVIÖ, 1971). LE solubility order.

Table 5. "Total" element content of the ploughed layer of certain sandy tobaccogrowing locations as a function of $\mathrm{pH}$ in 1991. (1) Name of location. (2) See Table 4. Note: Characterisation of locations using two mean samples from each field $(\mathrm{n}=2)$.

Table 6. Soluble element content of the ploughed layer of certain sandy tobaccogrowing locations as a function of $\mathrm{pH}$ in 1991. (1)-(2) and Note: see Table 5.

Table 7. Results of yield and leaf analysis for tobacco-growing areas in 1990 and 1991. (1) Measured or analysed parameters. a) Purchase price, thousand Forints/t; b) income, thousand Forints/ha; c) light-coloured, Grade B, \%; d) reducing sugars, \%; e) leaf yield, $\mathrm{t} / \mathrm{ha}$; f) total alkaloids, \%. (2) Mean.

Table 8. Leaf analysis data for tobacco-growing areas in 1990 and 1991 for each region and as a function of $\mathrm{pH}(\mathrm{KCl})$. A-E: see Table 3 .

Table 9. Leaf analysis data for certain sandy tobacco-growing locations as a function of pH in 1991. (1) and Note: See Table 5. (2) Reducing sugars. (3) Total N. (4) Alkaloids. 